$2 \mathrm{~L}$

Embryos:

Adult

(Males):

Adult

(Females):
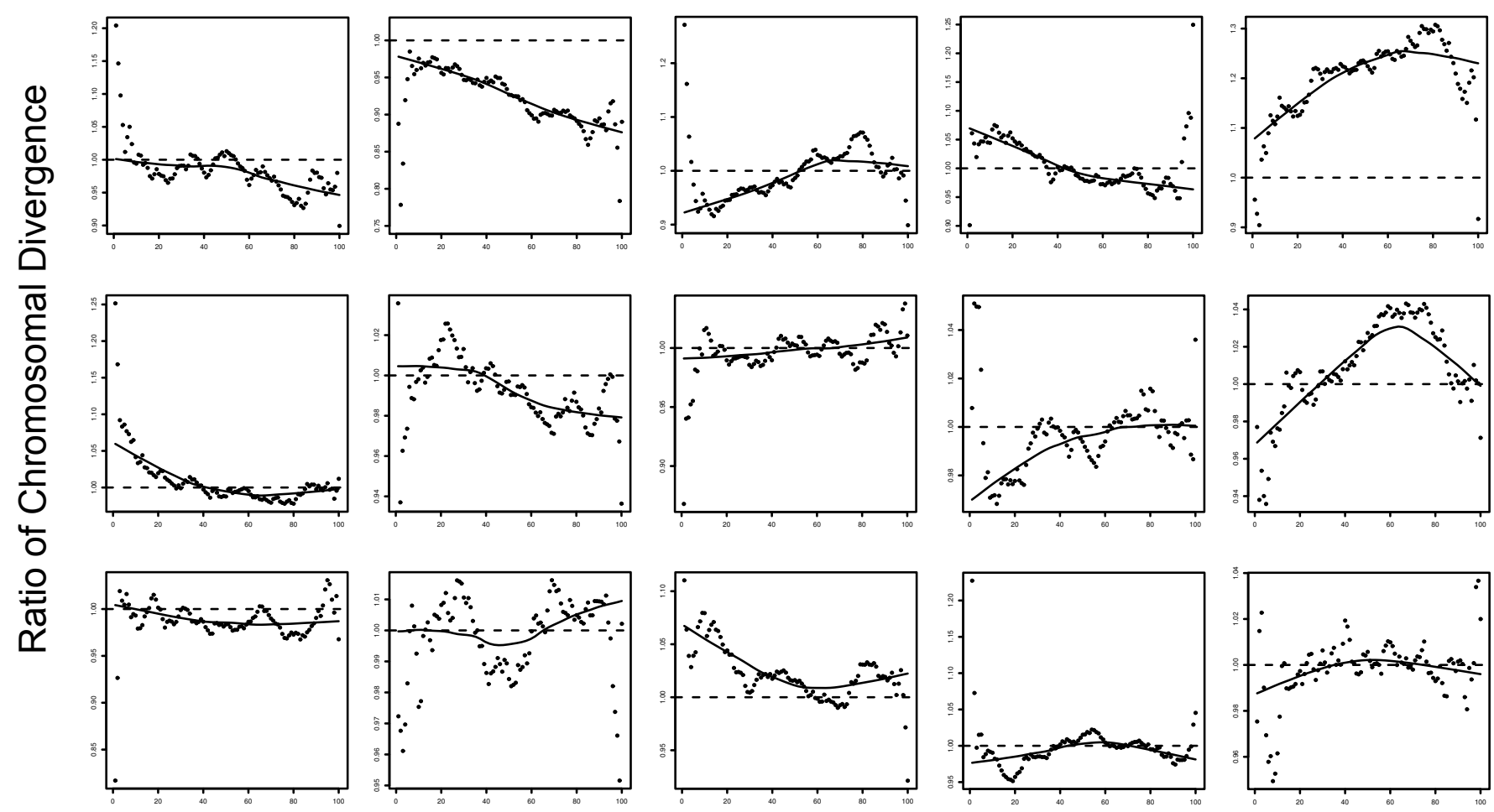

\title{
Ranked Divergence
}

(percentile of chromosomal divergence distribution) 